\title{
Racial Awareness in Phillis Wheatley's Selected Poems
}

\author{
Manimangai Mani* \\ English Department, Faculty of Modern Languages and Communication, \\ Universiti Putra Malaysia, Serdang, Selangor, Malaysia \\ E-mail address: manimangai@upm.edu.my
}

Keywords: slavery; racism; education; Blacks; racial awareness

\begin{abstract}
Slavery in America began when Africans were brought in as slaves to the North American Colony of Jamestown Virginia around 1619. Slavery in America lasted for almost four hundred years though the trade was legally abolished by Britain in March 1807 (Walvin 163). Although the trade ended, slavery itself continued to survive. Phillis Wheatley (1753-1784) is considered the first prominent Black writer in the United States to publish a book of imaginative writing. She is also the first to start the African-American literary tradition, as well as the AfricanAmerican women literary tradition. Her work, which was derivative, was published in the collection, Poems on Various Subjects (1773) and in various magazines. Her choice of words was mostly biblical where it helped to camouflage her view on slavery. This paper intends to show that all of Wheatley's poems actually carried the theme of freedom. She has intelligently used this theme to articulate her desires in a subtle manner. On the surface, the poems are all preaching the greatness of Christianity to the readers and urging them to find solace through religion. She shows her racial awareness and resistance through various themes of the poems that she wrote. This paper highlights Wheatley's disapproval of slavery through her praise for religion, political commentaries, supporting elegies and death and finally through her escapism into an imaginary world.
\end{abstract}

\section{INTRODUCTION}

'Some view the sable race with scornful eye--

'Their color is a diabolic dye;

'But know, ye Christians, Negroes black as Cain

'May be refined, and join the angelic train.'

Slavery in America lasted for almost four hundred years though the trade was legally abolished by Britain in March 1807 (Walvin 163). Although the slave trade ended, slavery itself continued to survive. The Atlantic Slave Trade is responsible for the transaction of about 12 million Blacks from Africa to the Americas. About 1.5 million were believed to have perished during the long voyage. There were about 27000 voyages from Africa that carried slaves to all over the Americas and Europe (Walvin 69). The first European slavers were the Portuguese. In 1441, Antam Gonvalvez captured twelve slaves from the coast of Africa and presented them to Prince Henry and late was approved by the Pope to go for more raids (Meltzer 1). Phillis Wheatley is a slave who is believed to be born in 1753 in West Africa, most probably in present day Senegal or Gambia. When she was about 8, she was taken on a slave ship called The Phillis to the British-ruled Boston, Massachusetts on July 11, 1761 (Odell, 9). She was bought by a merchant named John Wheatley to be a help to his wife Susanna. John and Susanna named the young girl Phillis, after the ship that had brought her to America. She was given their last name of Wheatley, as was a common custom if any surname was used for slaves.

Though she was a slave, Phillis did not share the same fate as her other counterparts. Although it was against the law to expose slaves to education, she was taught to read and write by Wheatley's children, Mary and Nathaniel. To teach a slave to read and write was forbidden under heavy penalties. In some states, the penalty for teaching the slave to read was heavier than for maiming him or putting out his eyes (Stowe). By the age of twelve, she was able to read Latin and Greek classics as well as the Bible. She wrote her first poem at the age of fourteen titled, "To the University of Cambridge, in New England". 
Phillis Wheatley (1753-1784) is considered the first prominent Black writer in the United States to publish a book of imaginative writing. She is also the first to start the African-American literary tradition, as well as the African-American women literary tradition. Her work, which was derivative, was published in the collection, Poems on Various Subjects (1773) and in various magazines. The second volume existed in manuscript but it was not published and was subsequently lost. Although Phillis traveled to England where she was much admired and soon thereafter obtained her freedom, she eventually died in poverty. All the existing poems written by Phillis show that she was a very religious person. She has written mostly elegies to the white folks. However, some of her poems express her happiness about being brought from Africa into the Christian society. The tone in most of her poems shows her thankfulness in being brought to the civilization and her exposure to Christianity. It also projects her thankfulness and obligations to Christianity. Her use of metre and rhyme-scheme is precise and correct. On the surface level, all her poems appear to be a medium to preach Christianity and supporting slavery for delivering the Africans from the pagan land and exposing them to Christianity. It will make one wonder why she had not used the opportunity to write about the horror of slavery when contemporary authors like Tony Morrison and Caryl Phillips would still use slavery as their theme in their novels. But anyone who ventures beneath the surface of her poem will definitely find it has much more to tell than what catches the eye. We must understand that Phillis lived in an era where slavery was still legal and that it was illegal for slaves to read and write. She was at the mercy of her master to get her poem published. Thus, is doesn't come as a surprise if the writings appears to be nothing but a bundle of praises for the white man's culture, religion and their act of enslavement. Whatever repressed feelings she had, she could only show them in a subtle manner. Her choice of words was mostly biblical where it helped to camouflage her view on slavery.

Although she expresses happiness of being exposed to Christianity and being brought to America from her pagan Africa, she is the first poet who actually wrote her lamentations on slavery. An in-depth and critical analysis will show that all of Phillis's poems actually carry the theme of freedom. She has intelligently used this theme to articulate her desires in a subtle manner. On the surface, the poems are all preaching the greatness of Christianity to the readers and urging them to find solace through religion.

\section{RACIAL AWARENESS THROUGH POETRY}

During the era of slavery, slaves were prohibited from learning how to read and write. However, Phillis Wheatley was lucky that she was bought by a couple that eagerly allowed her to learn how to read and write along with their daughter. She was abducted from Senegal when she was about seven or eight years old and was put in a slave auction in Boston in1761. In a way she was lucky that a wealthy tailor, John Wheatley, bought her for his wife Susanna as a companion. Mrs. Wheatley planned to train Phillis both to replace the aging house slaves and to be her companion, since Mrs. Wheatley's daughter, Mary would soon be old enough to leave home. Mary taught Wheatley to read and write. She also studied geography, history and Latin. She began to write poetry when she was about 14 (Richmond 15). Though she was always kept separated from the other slaves and was treated like a daughter, she never forgot her place in society as she always requested for a side table for eating her dinner separately. This clearly shows that she was fully aware of her position that, she does not fit in neither with the slaves nor the whites. More importantly it demonstrates how this black girl refused to forget her past and let herself to be pampered by the new culture her master tries to impose on her. The volumes of poems published had a Countess Huntingdon as her patron. Besides that it also carried a letter of consent from her master John Wheatley. The poems were written for the White readers. It is amazing to see how Wheatley was able convey her disappointment about slavery without being noticed by the Whites. She articulates the theme of freedom using several techniques (John Shields). 


\section{i. Freedom through religion}

Although, Wheatley has written many poems, she never showed any lamentation towards slavery openly. Most of the poems are elegies and praises for the Whites. However, one glance at her poems will tell readers how well Christianity has been used as a tool to brainwash the slaves brought from Africa to accept their misfortune as slaves. In her poem, On Being Brought from Africa to America, Wheatley says that it was mercy that she was brought from the pagan land and was introduced to Christianity.

\section{On Being Brought from Africa to America (1773)}

'Twas mercy brought me from my pagan land,

Taught my benighted soul to understand

That there's a God, that there's a Saviour too:

Once redemption neither sought nor knew.

Some view our sable race with scornful eye'

"Their color is a diabolic dye."

Remember, Christians, Negroes, black as Cain, May be refined, and join the angelic train.

Due to the exposure to Christianity, she has grown up thinking that Blacks were a cursed lot. She uses the biblical knowledge taught to her by her master, to relate the Blacks with the cruel son of Adam, Cain, who kills his own brother, Abel out of jealousy. From that incident, Cain was cursed by the Lord to shoulder his sins without salvation. This poem conveys a deep meaning to her race. She urges them to accept their fate as slaves and turn to religion for salvation. She states that although they are viewed as a cursed race, they can still attain freedom through religion in their afterlife.

Therefore, her poems show that she accepts her position as a slave happily without much confrontation, however she tells her fellow slaves that there is always hope for freedom through salvation. At the same time she is also putting across a subtle and yet cynical message to the slave masters that all slaves will one day be free when they leave this world. The masters cannot stop the slaves from attaining spiritual freedom. Lines 5 and 6 obviously show that she is indeed unhappy when her race is called as a doomed race and their colour has become an object of ridicule. However, she tells them that there is always freedom for them by being true Christians in their life hereafter.

\section{ii. Political comments supporting America's freedom from Britain.}

Wheatley makes political comments and shows enormous support to the American freedom from the British through her poems, To His Excellency General Washington. Before beginning the poem, she has written a letter addressed to General George Washington thanking and congratulating him on his efforts to obtain freedom for America. As a slave she is certainly not forgetting the fate of her fellow slaves and their own freedom from their masters. Wheatley who resided in Boston had witnessed the events leading to the Revolution. Therefore, she is able to make very intelligent commentary on the freedom of America.

\section{To His Excellency General Washington (1775)}

See mother earth her offspring's fate bemoan, And nations gaze at scenes before unknown!

See the bright beams of heaven's revolving light

Involved in sorrows and the veil of night!

The goddess comes, she moves divinely fair,

Olive and laurel binds her golden hair:

Wherever shines this native of the skies,

Unnumbered charms and recent graces rise. (Lines 5 to 12) 
The poem (Lines 5 - 12) above points out the greatness of the Statue of Liberty, that is, supposedly to represent America's independence and freedom. Wheatley claims that the Goddess is fair and just (Line 9). The irony of this poem is that it was written by a slave. She speaks of liberating America when she herself is not free. The freedom and independence of America is not going to do her any good. By supporting the independence of America she is actually hinting that an enslaved community still exist in a free America. We can see that there is so much hope in her poem for freedom where she states in lines 5- 12. These lines show the hidden dreams of her freedom from slavery. She is hoping that this goddess will bring freedom to the nation. But no nation is made of vacuum. It's the people who give life to a nation. Thus, it's a dream that the freedom for America will also be the mark of liberation for her enslaved race.

In another poem titled "To the Honorable Earl of Dartmouth", she mentions slavery by using the phrase dread the iron chain. Since only the Black slaves are chained, these lines definitely refer to her race. She subtly voices her disapproval against slavery of the fellow Blacks.

\section{To the Honorable Earl of Dartmouth (1772)}

She shines supreme, while hated faction dies:

Soon as appear'd the Goddess long desir'd,

Sick at the view, she languish'd and expir'd;

Thus from the splendors of the morning light

The owl in sadness seeks the caves of night.

No more, America, in mournful strain

Of wrongs, and grievance unredress'd complain,

No longer shalt thou dread the iron chain,

Which wanton Tyranny with lawless hand

Had made, and with it meant t' enslave the land. (Lines 10-19)

Though these lines seem to be singing the independence of America, however the 'iron chain' and 'lawless hand' definitely refers to the institution of slavery. Her aspirations for freedom from the institution of slavery are cleverly weaved in these lines.

\section{iii. Supports elegies and celebrates death}

Her numerous elegies suggest a conscious poetic escape from slavery. She celebrates death and the rewards of freedom afterlife. The following poem has been published on at least ten separate editions in cities such as Boston, New Port and Philadelphia. In 1770, it appeared in London and served to cement her international reputation as a talented poet.

On the Death of General Wooster (1778)

From native Clime, when

Seeming cruel Fate

Me snatched from Afric's fancy'd

Happy seat

...Ah! what bitter pangs

molest

What sorrows labour'd in the

Parent Breast?

That, more than stone, ne'er

Soft compassion mov'd

Who from its Father seiz'd his

Much belov'd.

But how, presumptuous shall

We hope to find

Divine appearance with th' 


\title{
Almighty mind- \\ While yet $(O$ deed \\ Ungenerous!) they disgrace \\ And hold in bondage Afric's \\ Blameless race? \\ Let virtue reign-And thou \\ Accord our prayers \\ Be victory our's, and generous \\ Freedom theirs."
}

Although this poem is supposed to mourn the death of General Wooster, Phillis has certainly taken this opportunity to lament about her position as a slave. She recalls how she was cruelly abducted from her native land. She relates how her loss would have affected her parents. She also notes how the whites oppress the blacks and hold them in bondage or slavery. However, she leaves it to the Almighty god who will give them freedom through the salvation of the soul by being true Christians.

\section{iv. Escapism through the world of imagination.}

Another way that Wheatley shows her racial awareness is through some of the elegies she wrote discussing freedom through the imaginative world. She uses poetry to escape to a world of imagination. However, she has not forgotten her fate as a slave who has to depend on the master for survival. Phillis married John Peters, a free African American in1778. By this time her master and his wife were dead and she was free. The burden of racist proved too much for Phillis, John and their three children. Peters put Phillis and the three children in a Negro boarding house where the foul condition resulted in the children's death and drastic decline in her health. While living in the boarding house, she wrote this poem.

\author{
America (1778) \\ Fearing his strength which \\ She undoubted knew \\ She laid some taxes on her \\ Darling son \\ He weeps afresh to feel this \\ Iron chain.
}

This poem obviously relates the treatment they got from the racist white even though they are supposedly free. This shows that the children though born free are still bound by this iron chain. Another perfect example that portrays her ability to seek freedom through escapism is the following poem. This poem was dedicated to the Right Honourable William, Earl of Dartmouth, His Majesty's Principal Secretary of State for North-America, \& co.

Right Honourable William, Earl of Dartmouth, His Majesty's Principal Secretary of State for North-America, \& co. (Lines 16-30).

Should you, my lord, while you peruse my song,

Wonder from whence my love of Freedom sprung,

Whence flow these wishes for the common good,

By feeling hearts alone best understood,

I, young in life, by seeming cruel fate

Was snatch'd from Afric's fancy'd happy seat:

What pangs excruciating must molest'

What sorrows labour in my parent's breast?

Steel'd was that soul and by no misery mov'd 
That from a father seiz'd his babe belov'd:

Such, such my case. And can I then but pray

Others may never feel tyrannic sway?

This is the poem that she has lamented her fate openly. She recalls her abduction and her father's sorrow after losing her to the slavers.

\section{CONCLUSION}

Phillis Wheatley died in 1784 due to asthma and poverty. Although she was free on paper, she was never free from the racist white. The freedom that she obtained and the talent she had did not let her survive freely in the harsh white dominated world. Wheatley is a poet who demonstrates remarkable literary maturity and a profound Christian spirituality. Literacy gives her the advantage that is unimaginable to her other comrades. She uses them to fool her White masters into thinking that she is hailing them when in actual sense she is crying out to her deprived race. Although racial equality is not a theme to be found in her poetry, she has used the theme of freedom to voice her dissatisfaction against slavery of the Blacks in a very subtle manner. She was the first African American to write about the impact and misfortune of slavery in America. It would take another hundred years for another Black writer who could write and relate the African American experiences as slaves in America.

\section{REFERENCES}

[1] Gundaker, Grey (2007). Hidden Education among African Americans during slavery. The Teachers College Record 109.7 (2007) : 1591-1612.

[2] Meltzer, Milton (1993). Slavery, A World History Vol. II. Chicago: Da Capo Press.

[3] Odell, Matilda (1999) Memoir and Poems of Phillis Wheatley, a Native African and a Slave. Dedicated to the Friends of the Africans, University of North Carolina at Chapel Hill: Academic Affairs Library, UNC-CH.

[4] Stowe, Harriet Beecher. " The Education of Freedman”, The North American Review 128.271 (1879): 606 -15. Jstor. University of Northern Iowa. Web. 24 Sept, 2014.

[5] Wheatley, Phyllis (1988). John C. Shields. ed. The Collected Works of Phillis Wheatley. New York: Oxford University Press.

[6] Wheatley, Phyllis (2001). Vincent Carretta. ed. Complete Writings. New York: Penguin Books.

[7] Walvin, James (2007). A Short History of Slavery. London: Penguin Books.

[8] Washington, Booker T. The Negro Problem, New York : J Pott and Company, 1903.

[9] Washington, Booker T. Up from Slavery. New York : Penguin Books, 1986. 